\title{
ПРОФІЛАКТИКА ПЛАЦЕНТАРНОЇ ДИСФУНКЦІЇ У ЖІНОК ГРУП РИЗИКУ. ОЦІНКА РЕЗУЛЬТАТІВ
}

Вищий державний навчальний заклад України «Буковинський державний медичний університет», м. Чернівці

Резюме. Профілактика перинатальної патології та збереження здоров'я вагітної є однією з найактуальніших проблем сучасної медицини. Незважаючи на чисельні наукові розробки над вирішенням даної проблеми, частота порушень у системі мати-плацента-плід сягає $60-70 \%$.

Основну групу сформували 70 вагітних, IA $(\mathrm{n}=35)$ - вагітні з проявами плацентарної дисфункції без специфічної профілактики плацентарної дисфункції, IB (n=35) - вагітні зі специфічною профілактикою плацентарної дисфункції. Контрольна група - 40 здорових вагітних. Наведені результати ефективності проведеної профілактики плацентарної дисфункції у жінок групи ризику, які оцінені завдяки клінічним, лабораторним, інструментальним, імуногістохімічним та гістологічним методами досліджень

Вступ. Профілактика перинатальної патологіï та збереження здоров'я вагітної $€$ однією 3 найактуальніших проблем сучасної медицини.

Зважаючи, що за останнє десятиріччя в Україні значно погіршилася демографічна ситуація і при цьому зберігаються високі показники перинатальних ускладнень, надзвичайно актуальним для практичного акушерства є вивчення різноманітних чинників ризику порушень стану матері і плода $[4,5]$. Серед них вагоме місце відводять плацентарній дисфункції (ПД), яка супроводжує значну частку ускладнень вагітності: у пацієнток 3 прееклампсією вона трапляється у $66,3 \%$ [1, 2, 3], 3 невиношуванням інфекційного генезу - у 50-60 \% [2, 4], із синдромом затримки розвитку плода - у 63-68 \% [6]. Незважаючи на чисельні наукові розробки над вирішенням даної проблеми, частота порушень у системі матиплацента-плід сягає 60-70 \% [5].

Мета дослідження. Проаналізувати ефективність проведеної профілактики плацентарної дисфункції в жінок груп ризику згідно з лабораторними, інструментальними, імуногістохімічними та гістологічними показниками.

Матеріал і методи. Для оцінки ефективності профілактики плацентарної дисфункції проведено дослідження визначення рівня гормонів: естрадіолу, прогестерону, плацентарного лактогену, кортизолу в сироватці крові вагітних. Показники ендокринної функції визначали методом твердофазового імуноферментного аналізу з використанням тест-систем, що основані на дії моноклональних антитіл (ДИАМЕБ, Україна). Білоксинтезувальну функцію вивчали методом твердофазового імуноферментного аналізу з використанням тест-систем, що основані на дії моноклональних антитіл (ДИА-М, Москва). Дослідження концентрації специфічних трофобластичного $\beta 1$ -

(C) А.В. Гошовська, I.В. Бирчак, В.М. Гошовський, 2016
Ефективність проведеної нами профілактики плацентарної дисфункції оцінювали за показниками досліджень у жінок IA та IB підгрупи основної групи. Слід відзначити, що в жінок IB підгрупи (з проведеною специфічною профілактикою дисфункції плаценти) лабораторні, інструментальні, імуногістохімічні та гістологічні дані позитивно відрізнялися від показників IA підгрупи.

Запропонована методика профілактики порушень плацентарного комплексу дозволяє досягти кращих результатів щодо більшості показників, а у відношенні до окремих процесів у плаценті дозволяє довести їх до рівня фізіологічної вагітності.

Ключові слова: плацентарна дисфункція, вагітність, гормони, білки, цитотрофобласт.

глікопротеїну (ТБГ) та плацентарного $\alpha$ 1мікроглобуліну (ПАМГ) білків у сироватці крові у вагітних основної та контрольної груп.

Ультразвукове дослідження (УЗД) проводили з використанням УЗД-апарата «ALOKA-1400» iз застосуванням датчика 3 частотами 5,0 та 7,5 МГц. Обстеження виконували в термінах 2024, 28-32 та 36-38 тижнів вагітності, яке включало фетометрію, оцінку стану плода, виявлення маркерів хромосомних аномалій і внутрішньоутробного інфікування плода, плацентографію, оцінку якості навколоплідних вод, доплерометрію.

Макроскопічну характеристику плаценти здійснювали описовим методом, згідно з органометричними параметрами, які є найбільш інформативними для оцінки плацентарної недостатності. Для гістологічного та гістохімічного дослідження плацентарну тканину забарвлювали за методикою Н.3. Слінченка. Проводили імуногістохімічні методики на плацентарний лактоген та ТБГ.

Для проведення поставлених нами завдань жінки були розподілені на дві групи. Основну групу сформували 70 вагітних, IA (n=35) - вагітні 3 проявами плацентарної дисфункції без специфічної профілактики плацентарної дисфункції, IB $(\mathrm{n}=35)$ - вагітні зі специфічною профілактикою плацентарної дисфункції. Контрольна група - 40 здорових вагітних. Клінічно-лабораторне дослідження проводили відповідно до Наказу МO3 України.

Результати дослідження та їх обговорення. За умови пролонгації вагітності в жінок із проявами невиношування, вагітним до комплексу лікувальних заходів призначали гормональну терапію препаратом урожестан по 100мг вагінально двічі на добу до 20 тижнів вагітності. За такого лікування спостерігали позитивну динаміку клінічних та лабораторно-інструментальних 
даних, а в третини вагітних - приріст фетометричних показників.

Після 22-23 тижнів вагітності з метою профілактики плацентарної дисфункції (ПД) у комплексному лікуванні вагітних із ПД використовували препарат цитофлавін та озонований 0,9 \% розчин $\mathrm{NaCl}$.

Препарат цитофлавін застосовували зважаючи на низку обгрунтованих клінічно-лабораторних та морфологічних ланок патогенезу ураження фетоплацентарного комплексу (ФПК).

До складу діючої речовини 1 мл цитофлавіну входить 100 мг бурштинової кислоти, нікотинаміду 10 мг, рибоксину 20 мг, рибофлавіну мононуклеотиду (рибофлавіну) 2мг. Фармакологічний ефект зумовлений комплексним впливом антигіпоксичних речовин, які входять до складу компонентів препарату цитофлавін. Препарат стимулює дихання й енергоутворення в клітинах, поліпшує процеси утилізації кисню тканинами, відновлює активність ферментів антиоксидантного захисту. Цитофлавін активує внітрішньоклітинний синтез білка, сприяє утилізації глюкози, жирних кислот і ресинтезу в нейронах гаммааміномасляної кислоти (ГАМК). Стимулює синтез АТФ, підсилює проліферацію пошкоджених клітин, ангіогенез, створює сприятливі умови для синтезу колагену і росту грануляційної тканини, покращує обмін у тканинах, підтримує і відновлює енергетичний метаболізм та окисне фосфорилювання, забезпечує високоенергетичними фосфатами клітини, які знаходяться в умовах дефіциту живлення.

Цитофлавін призначали жінкам основної групи по 10 мг (1 мл) у 200 мл $0,9 \%$ ізотонічного розчину натрію хлориду або $5 \%$ розчині глюкози 1 раз на добу через день.

Поєднання медичного озону на тлі комплексної терапії покращує матково-плацентарний та плодово-плацентарний кровообіг за рахунок нормалізації судинної резистентності в маткових, спіральних та плацентарних артеріях. Механізмом дії озонованого фізіологічного розчину $\epsilon$ активація біоенергетичних процесів на клітинному рівні, покращання мембранного стану формених елементів крові і зниження їхньої агрегаційної здатності, позитивний вплив на гемореологію i периферичну гемодинаміку, що призводить до нормалізації мікроциркуляції, покращення віддачі кисню тканинам. Під впливом озону відбувається активний ріст тонкостінних судин з розширенням та збільшенням їхньої довжини. Останній сприятливо впливає на функцію органів (міометрій, плацента), які перебувають у стані гіпоксії. Застосування медичного озону не тільки позитивно впливає на перебіг вагітності та плацентарний комплекс.

Озонований фізіологічний розчин готували шляхом пропускання через флакон із стерильним розчином $0,9 \%$ хлористого натрію озонокисневої суміші 3 концентрацією озону 0,4-1,5 мг/л. Отриманий розчин одразу вводили в ліктьо- ву вену крапельно зі швидкістю 8-10 мл/хв протягом 30-40 хв.

Ефективність проведеної нами профілактики ПД оцінювали за показниками наших досліджень в жінок IA та IB підгрупи основної групи. Слід відзначити, що у жінок IB підгрупи (з проведеною специфічною профілактикою дисфункції плаценти) лабораторні, інструментальні, імуногістохімічні та гістологічні дані позитивно відрізнялися від показників IA підгрупи. При гормональному дослідженні рівень естрадіолу, прогестерону, плацентарного лактогену при проявах ПД був значно нижчим, ніж при фізіологічній вагітності (контрольна група), але запропонована нами методика профілактики дозволила вірогідно підвищити показники $(\mathrm{P}<0,05)$. Рівень вказаних гормонів порівняно зі стандартною методикою профілактики (IA підгрупа) підвищувався. Зокрема, рівень естрадіолу в жінок IB підгрупи був вищим при запропонованій методиці профілактики $44,7 \pm 1,14$ (нмоль/л) порівняно 3 жінками IA групи 41,4 1,12 (нмоль/л), рівень прогестерону у жінок IB підгрупи становив 579,1 44,86 (нмоль/л) проти 538,6 44,14 (нмоль/л), рівень плацентарного лактогену становив у підгрупі IB 277,0 44,11

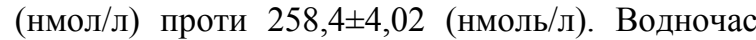
рівень кортизолу при застосованій нами профілактиці плацентарної дисфункції, на відміну від інших гормонів, особливо не відрізнявся (P> $0,05)$.

Оцінюючи показники білокпродукувальної функції плаценти встановлено, що рівень ТБГ при застосуванні запропонованої методики про-

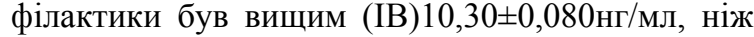
при стандартній методиці профілактики 9,52 $\pm 0,075$ нг/мл (IA). При цьому запропонована методика профілактики дозволила досягти рівень ТБГ майже до цифр контрольної групи $10,34 \pm 0,074$ нг/мл. Інші закономірності були відзначені за ПАМГ. Зокрема, запропонована методика профілактики дозволила більш суттєво знизити рівень ПАМГ, а саме: для групи IB $62,11 \pm 0,27$ нг/мл порівняно 3 жінками підгрупи IA $80,1 \pm 0,52$ нг/мл. Слід відзначити, що жоден із застосованих методів профілактики не дозволив досягти стану фізіологічної вагітності $35,6 \pm 0,12$ нг/мл ( контрольна група).

При імуногістохімічному дослідженні встановлено, що концентрація плацентарного лактогену в трофобласті хоріональних ворсин у підгрупі IB дещо покращила показники даного гормону $0,295 \pm 0,0127$ у.о.опт.густ. порівняно із стандартною методикою профілактики (група I A) 0,241 $\pm 0,0154$ у.о.опт.густ. При визначенні плацентарного лактогену в інвазивному трофобласті матково-плацентарної ділянки відзначені позитивні результати у групі IB $(0,298 \pm 0,0123$ у.о. опт.густ.) порівняно 3 групою IA $(0,221 \pm 0,0125$ у.о.опт.густ.). Позитивний результат відзначений у підгрупі IB при досліджені ТБГ у трофобласті хоріальних ворсинок $(0,325 \pm 0,0126$ у.о.опт.густ.). Проте концентрація ТБГ порівняно з жінками, які 
отримували стандартну схему профілактики ПД (IA), становила $(0,279 \pm 0,0134$ у.о.опт.густ.).

Морфологічні зміни в плацентах дали змогу обгрунтувати окремі ланки патогенезу більш високої ефективності запропонованого методу профілактики порівняно зі стандартним методом. Зокрема, це стосується інвазивних функцій цитотрофобласта матково-плацентарної ділянки. Так, у відношенні до показника «середня кількість цитотрофобластичних клітин» запропонований метод профілактики порівняно зі стандартним виявився більш ефективним. Показник «середня кількість цитотрофобластичних клітин» нормалізувався і значно перевищував величину показника у групі зі стандартною профілактикою ПД

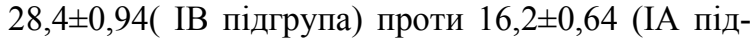
група).

Визначаючи оптичну щільність специфічного імуногістохімічного дослідження протеїну BAX у цитоплазмі цитотрофобластичних клітин матково-плацентарної ділянки, встановлено, що даний показник знижувався в підгрупі IB $0,332 \pm 0,0034$ порівняно 3 підгрупою IA $0,423 \pm 0,0061$. Застосування цитофлавіну, у комплексному поєднанні з озонованим фізіологічним розчином, зменшує інтенсивність ВАХзалежного апоптозу інвазивного цитотрофобласта матково-плацентарної ділянки до фізіологічного рівня $0,329 \pm 0,0086$, що дає змогу зберегти необхідну кількість клітин цитотрофобласта для здійснення його інвазивних функцій.

Оцінюючи частоту ПД, відзначено, що в підгрупі IB значно менше траплялися акушерські ускладнення порівняно $з$ жінками, яким застосовували традиційну методику профілактики дисфункції плаценти (IA). Так, частота гіпотрофії плода та показник СЗРП I ступеня (симетрична форма) траплялися менше на 7,1 \% у групі IB, гіпоплазія плаценти рідше спостерігалася в жінок підгрупи IB на 1,4 \% Помірне багатоводдя значно менше (на 15,7 \%) було відзначено у підгрупі IB.

Найбільш доказові зміни при КТГ дослідженні відзначено для наступних показників: базальна частота серцевих скорочень (БЧЧ), кількість, амплітуда та тривалість акселерації і децелерації. Відзначено, що в жінок, які отримували специфічну профілактику ПД, значно кращі результати були зареєстровані КТГ дослідження порівняно 3 жінками, які отримували традиційну профілактику дисфункції плаценти. Так, БЧСС на 9,8 \% перевищувала показники у підгрупі IB порівняно 3 показниками жінок IА підгрупи. Відзначено, що кількість, амплітуда та тривалість акцелерацій значно більше спостерігались у жінок IB підгрупи, що характеризувало позитивний внутрішньоутробний стан плода. Кількість акцелерацій у групі IB перевищувала показники на 41,9 \%, амплітуда акцелерацій IB підгрупі перевищувала показники на 18 \%, триваліші акцелерації були зареєстровані у жінок із проведеною специфічною профілактикою дисфункції плаценти - у підгрупі IB - на 31,8 \%. Встановлено, що кількість, амплітуда та тривалість децелерацій значно підвищувалися в жінок із традиційною методикою профілактики ПД (IA), що свідчило про негативний внутрішньоутробний стан плода.

\section{Висновок}

Оцінюючи позитивні результати з боку гормональної, білокпродукувальної системи, даних інструментального, морфологічного та імуногістохімічного дослідження у вагітних із застосуванням запропонованої нами профілактики плацентарної дисфункції (IB підгрупі) можна дійти висновку, що традиційні методи профілактики плацентарної дисфункції не спроможні суттєво вплинути на порушення та покращення показників до фізіологічного рівня. Водночас запропонована власна методика дозволяє досягти кращих результатів щодо більшості показників, а стосовно окремих процесів у плаценті дозволяє довести їх до рівня фізіологічної вагітності.

Перспективи подальших досліджень. Перспективи даного дослідження пов'язані з розкриттям взаємозв'язку представлених даних 3 клінічними проявами плацентарної дисфункції.

\section{Література}

1. Бесєдін В.М. Стан гормональної функції плаценти у немолодих першородячих, можливості комплексної терапії фетоплацентарної недостатності / В.М. Бесєдін, М.В. Дорошенко-Кравчик // Вісн. наук. досліджень. - 2006. - № 2 (35). - С. 227-229.

2. Каліновська І.В. Дослідження рівня плацентарного $\alpha_{1}$ мікроглобуліну в материнській сироватці крові при плацентарній формі фетоплацентарної недостатності у різні терміни вагітності / І.В. Каліновська // Одес. мед. ж. -2008 . - № 2. - C. 53-55.

3. Рец Ю.В. Гормонально-гистометрические корреляции при хронической плацентарной недостаточности / Ю.В. Рец // Вопр. гинекол., акуш. и перинатол. - 2008. - T. 7, № 1. - C. 12-15.

4. Филиппов О.С. Прогностическая значимость различных методов диагностики фетоплацентарной недостаточности / О.С. Филиппов, А.А. Казанцева // Пробл. репродукции. -2007 . - № 3. - С. 60-63.

5. Чепка Ю.Л. Прогнозування фетоплацентарної недостатності на основі статистичного багатофакторного комп'ютерного аналізу / Ю.Л. Чепка // Укр. мед. часопис. - 2009. - № 1 (33). - С. 105-108.

\section{ПРОФИЛАКТИКА ПЛАЦЕНТАРНОЙ ДИСФУНКЦИИ У ЖЕНЩИН ГРУПП РИСКА. ОЦЕНКА РЕЗУЛЬТАТОВ}

\section{А.В. Гошовская, И.В. Бырчак, В.М. Гочовский}

Резюме. Профилактика перинатальной патологии и сохранения здоровья беременной является одной из самых актуальных проблем современной медицины. Несмотря на многочисленные научные разработки над решением данной проблемы, частота нарушений в системе мать-плацента-плод достигает 60-70 \%.

Основную группу составили 70 беременных, IA (n=35) - беременные с проявлениями плацентарной дисфунк- 
ции без специфической профилактики плацентарной дисфункции, IB (n=35) - беременные со специфической профилактикой плацентарной дисфункции. Контрольная группа - 40 здоровых беременных. Приведены результаты эффективности проведенной профилактики плацентарной дисфункции у женщин группы риска, которые были оценены благодаря клиническим, лабораторным, инструментальным, иммуногистохимическим и гистологическим методами исследований.

Эффективность проводимой нами профилактики плацентарной дисфункции оценивали по показателям наших исследований у женщин IA и IB подгруппы основной группы. Следует отметить, что у женщин IB подгруппы (с проведенной специфической профилактикой дисфункции плаценты) лабораторные, инструментальные, иммуногистохимические и гистологические данные положительно отличались от показателей IA подгруппы.

Предложенная методика профилактики нарушений плацентарного комплекса позволяет достичь лучших результатов по большинству показателей, а в отношении отдельных процессов в плаценте позволяет довести их до уровня физиологической беременности.

Ключевые слова: плацентарная дисфункция, беременность, гормоны, белки, цитотрофобласт.

\section{PREVENTION OF PLACENTAL DYSFUNCTION IN WOMEN AT RISK. EVALUATION OF THE RESULTS}

\section{A.V. Hoshovska, I.V. Byrchak, V.M. Hoshovskyy}

Abstract. Prevention of perinatal pathology and preservation of health of a pregnant is one of the most urgent problems of modern medicine. Despite numerous scientific developments on solving this problem, the frequency of disturbances in the system mother-placenta-fetus reaches $60-70 \%$.

The main group consisted of 70pregnant women, IA $(n=35)$ - pregnant women with symptoms of placental dysfunction without specific prevention of placental dysfunction, IB $(n=35)$ - pregnant with the specific prevention of placental dysfunction. The control group included 40 healthy pregnant women. Given the results of the effectiveness of prevention of placental dysfunction in women at risk who were evaluated through clinical, laboratory, instrumental, histological and immunohistochemical methods of research.

The effectiveness of our prevention of placental dysfunction was evaluated in terms of our studies in women IA and IB subgroups of the main group. It should be noted that women IN the subgroup (with a specific prevention of dysfunction of the placenta) of the laboratory, instrumental, histological and immunohistochemical data were positively different from the IA subgroup.

The proposed method of prevention of placental disorders of the complex allows to achieve the best results for most indicators, and in relation to individual processes in the placenta allows you to bring them to the level of physiological pregnancy.

Key words: placental dysfunction, pregnancy hormones, proteins, cytotrophoblast.

Higher State Educational Institution of Ukraine "Bukovinian State Medical University” (Chernivtsi)

Рецензент - проф. І.С. Давиденко

Buk. Med. Herald. - 2016. - Vol. 20, № 3 (79). - P. 49-52

Надійшла до редакції 29.06.2016 року

(C) А.В. Гошовська, І.В. Бирчак, В.М. Гошовський, 2016 